\title{
Synthesis of $\mathrm{Cr}$ (III)-Aspartate and $\mathrm{Cu}$ (II)-Aspartate Complexes as Antidiabetic Compound
}

\author{
Yuli Ambarwati*, Dinda S. Firguna, Syaiful Bahri, Aspita Laila and Sutopo Hadi*
}

Department of Chemistry, Faculty of Mathematics and Natural Sciences, Universitas Lampung, Bandar Lampung, 35145, Indonesia

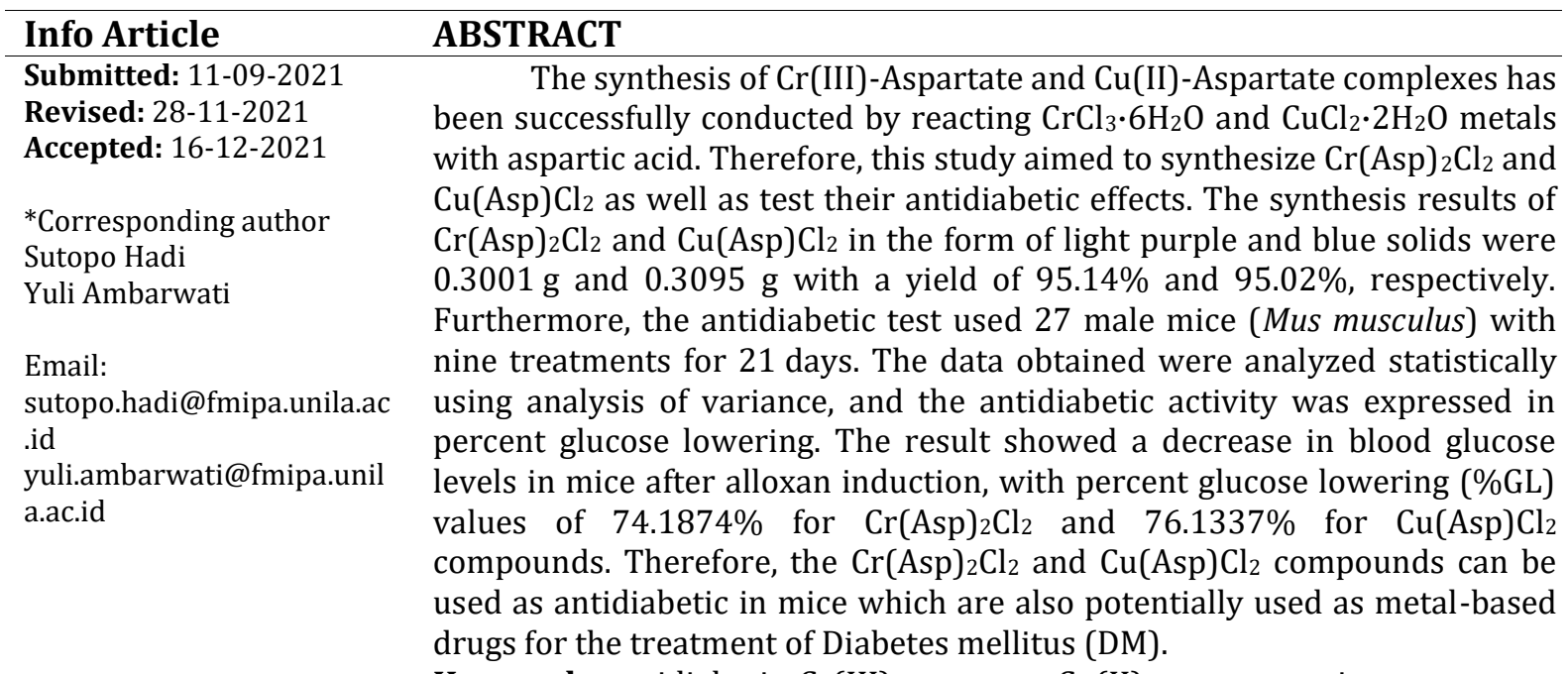

Keywords: antidiabetic, $\mathrm{Cr}(\mathrm{III})$-aspartate, $\mathrm{Cu}(\mathrm{II})$-aspartate, mice

\section{INTRODUCTION}

Diabetes mellitus (DM), one of the top ten causes of death worldwide, is a disease caused by high blood sugar. It has caused the deaths of 1.6 million people in 2016 of which $90 \%$ had type 2 diabetes (WHO, 2018). Type 2 DM is caused by an inactive insulin receptor, which results in insulin not working optimally (DeFronzo et al., 2015). Type 2 DM is a chronic metabolic disorder in which prevalence has been increasing steadily all over the world (Olokaba et al., 2012).

Many inorganic compounds have been used and tested their biological activities as antimalarial (Hadi et al., 2018; Hansch and Verma, 2009), anticancer and antitumor (Gielen, 2003; Rehman et al. 2009; Hadi et al., 2010; Hadi et al., 2012), antifungal (Joshi et al., 2020), antibacterial (Annissa et al., 2017, Hadi et al., 2021; Samsuar et al., 2021), inhibitor corrosion (Hadi et al., 2015; Kurniasih et al., 2015; Hazani et al., 2019). The study on various metal complexes have also shown very interesting antidiabetic activities, the metals include chromium, manganese, molybdenum, copper, cobalt, zinc, tungsten and vanadium (Thompson et al., 2004; Budiasih et al., 2013b; Sundaramurthy et al., 2016).
One of the transition metals used for the treatment of DM is chromium(III), which plays a role in increasing the sensitivity of insulin receptors to interact with insulin (Cefalu and $\mathrm{Hu}$, 2004; Lewicki et al., 2014). These receptors can activate glucose transport to enter the cell membrane, and also to enhance the distribution and energy converting functions (Krejpcio, 2001; Lewicki et al., 2014). In addition, the Cr(III) is a glucose tolerance factor (GTF), which functions to activate insulin receptors to increase the activity of glucose metabolism into energy and the effectiveness of insulin (Anderson, 2000).

The use of Cr(III) with amino acids in the form of new compounds is a potential opportunity for antidiabetic applications, and in this study, aspartic acid contained in GTF was used. Besides chromium, copper (II) metal can also act as an antidiabetic $\mathrm{Cu}$ metal with a Schiff base, which is synthesized and tested as an antidiabetic with a glucosidase inhibition value of $0.40 \%(4 \mu \mathrm{g} / \mathrm{mL})$ in complex 1 (N-(salicylidene)-L-valine) and $2(\mathrm{~N}$ (3,5-dichlorosalicyliden)-L-valine) of $0.05 \%$ $(0.5 \mu \mathrm{g} / \mathrm{mL})$. Therefore, $\mathrm{Cu}$ metal with a Schiff base has diabetes inhibitory activity (Sundaramurthy et al., 2016). $\mathrm{Cr}(\mathrm{III})$ and $\mathrm{Cu}(\mathrm{II})$ metal complex 
compounds were synthesized with aspartic acid; the compounds formed were tested on male mice to determine the activity of antidiabetic compounds.

\section{MATERIALS AND METHODS \\ Materials and Instrumentation}

The materials used include $\mathrm{CrCl}_{3} \cdot 6 \mathrm{H}_{2} \mathrm{O}$, $\mathrm{CuCl}_{2} \cdot 2 \mathrm{H}_{2} \mathrm{O}$, amino acid aspartic acid, sodium hydroxide solution ( $1 \mathrm{M} \mathrm{NaOH}$ ), alloxan, $5 \mathrm{mg}$ glibenclamide, $0.9 \% \mathrm{NaCl}$, distilled water, double distilled water, aluminum foil, sugar strips, feed mice in the form of pellets, alcohol swab, and instrumentation: UV-Vis spectra were obtained using UV-Vis spectrophotometer Hitachi U-2010, the IR spectra were measured using FT-IR Bruker VERTEX 70 spectrophotometer, and SEM-EDX analysis was conducted using Scanning Electron Microscope (SEM-EDX) ZEISS EVOß MA 10.

\section{Synthesis and Characterization of $\mathrm{Cr}(\mathrm{Asp})_{2} \mathrm{Cl}_{2}$ and $\mathrm{Cu}(\mathrm{Asp}) \mathrm{Cl}_{2}$}

The synthesis of $\mathrm{CrCl}_{3} \cdot 6 \mathrm{H}_{2} \mathrm{O}$ with aspartic acid was conducted at a ratio of $1: 3 \mathrm{mmol}$ using the procedure reported by Budiasih et al. (2013a). The $\mathrm{CrCl}_{3} \cdot 6 \mathrm{H}_{2} \mathrm{O}$ solution was prepared by dissolving $0.26 \mathrm{~g}(1 \mathrm{mmol}) \mathrm{CrCl}_{3} \cdot 6 \mathrm{H}_{2} \mathrm{O}$ in $25 \mathrm{~mL}$ distilled water. Meanwhile, the aspartic acid solution was prepared by dissolving $0.39 \mathrm{~g}$ ( $3 \mathrm{mmol}$ ) aspartic acid in $25 \mathrm{~mL}$ distilled water. The two were mixed and added with $0.1 \mathrm{M}$ $\mathrm{NaOH}$ solution at varying $\mathrm{pH}(2,4,5,6$, and 7), refluxed at $60^{\circ} \mathrm{C}$ with time variations $(1,2,3$, and $4 \mathrm{~h}$ ), and frozen dry for $48 \mathrm{~h}$ (Yang et al., 2005). Furthermore, the synthesis of $\mathrm{CuCl}_{2} \cdot 2 \mathrm{H}_{2} \mathrm{O}$ with aspartic acid was conducted at a ratio of $1: 2 \mathrm{mmol}$ in line with the previously performed procedure. The $\mathrm{CuCl}_{2} \cdot 2 \mathrm{H}_{2} \mathrm{O}$ and aspartic acid sample solutions were prepared by dissolving $0.17 \mathrm{~g}(1 \mathrm{mmol}) \mathrm{CuCl}_{2} \cdot 2 \mathrm{H}_{2} \mathrm{O}$ and $0.26 \mathrm{~g}$ ( $2 \mathrm{mmol}$ ) aspartic acid in $25 \mathrm{~mL}$ distilled water respectively. Thereafter, the next treatment conducted was similar to the synthesis of $\mathrm{Cr}(\mathrm{Asp})_{2} \mathrm{Cl}_{2}$.

The characterization of $\mathrm{Cr}(\mathrm{Asp})_{2} \mathrm{Cl}_{2}$ and $\mathrm{Cu}$ (Asp) $\mathrm{Cl}_{2}$ complex compounds was conducted using a UV-Vis spectrophotometer at a wave length of 300-1000 nm. Furthermore, IR was conducted to identify the functional groups present in the $\mathrm{Cr}(\mathrm{Asp})_{2} \mathrm{Cl}_{2}$ and $\mathrm{Cu}(\mathrm{Asp}) \mathrm{Cl}_{2}$ complex compounds at wavenumbers 4000$400 \mathrm{~cm}^{-1}$.

\section{Antidiabetic Test}

The antidiabetic test was conducted based on the reported procedure available in the literature (Sharma et al., 2011; Budiasih et al., 2013b; Ariastuti et al., 2020) and as following: male mice (Mus musculus) between 3-4 months old and weighing 30-40 g, as many as 27 were used. Before treatment, 27 mice were acclimatized for 7 days in order to get adapted to the new environment and minimize the effects of stress that can affect their metabolism. During the acclimatization process, they were given food and water ad libitum until they were satisfied. All treatment groups were induced by alloxan by injecting the solution subcutaneously at the nape of the neck using $150 \mathrm{mg} / \mathrm{kgbw}$. It aimed to make the mice to become diabetic. Based on the American Diabetes Association, the criteria for diabetes diagnosis are an increase in blood glucose levels (hyperglycemia) $\geq 126 \mathrm{mg} / \mathrm{dL}$.

\section{RESULTS AND DISCUSSION}

The Synthesis of $\mathrm{Cr}(\mathrm{Asp})_{2} \mathrm{Cl}_{2}$

The synthesis results of $\mathrm{Cr}(\mathrm{Asp})_{2} \mathrm{Cl}_{2}$ were obtained in the form of light and blackish purple solids. In the complex without the addition of $\mathrm{NaOH}$, it was obtained that a solid of $0.3543 \mathrm{~g}$ was blackish purple. However, at pH 4 and 5, it had a light purple color of 0.4001 and $0.2645 \mathrm{~g}$, respectively; and at $\mathrm{pH} 6$, it was $0.2432 \mathrm{~g}$ in the form of blackish purple (Figure 1). The characterization using a UV-Vis spectrophotometer shows the shift in wavelengths after reacting $\mathrm{CrCl}_{3} \cdot 6 \mathrm{H}_{2} \mathrm{O}$ with aspartic acid (Figure 2).

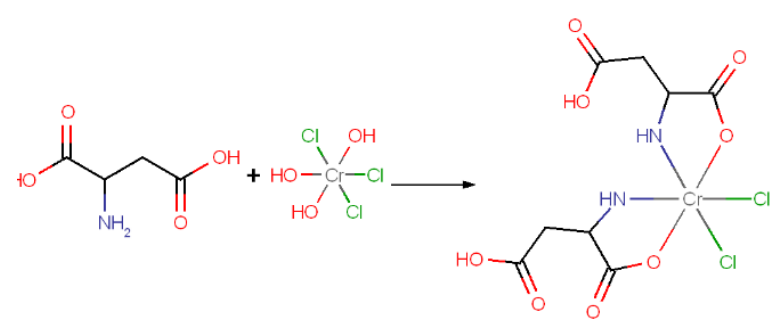

Figure 1. The reaction between $\mathrm{Cr}$ (III) and aspartic acid.

The maximum wavelength $\left(\lambda_{\max }\right)$ of $\mathrm{CrCl}_{3} \cdot 6 \mathrm{H}_{2} \mathrm{O}$ metal (439 and $630 \mathrm{~nm}$ ), toward a smaller one in the $\mathrm{Cr}(\mathrm{Asp})_{2} \mathrm{Cl}_{2}$ complex at $\mathrm{pH} 2$ (408 and $599 \mathrm{~nm}$ ) and at $\mathrm{pH} 4$ (383 and $538 \mathrm{~nm}$ ) (Figure 2 (a)). This shows that there has been a reaction between $\mathrm{CrCl}_{3} \cdot 6 \mathrm{H}_{2} \mathrm{O}$ and aspartic acid. 
The shifting toward a smaller wavelength is called a blue shift (hypsochromic) and it occurs when the increase in the solvation of the electron pair results in a decrease in the $n$ orbital energy.

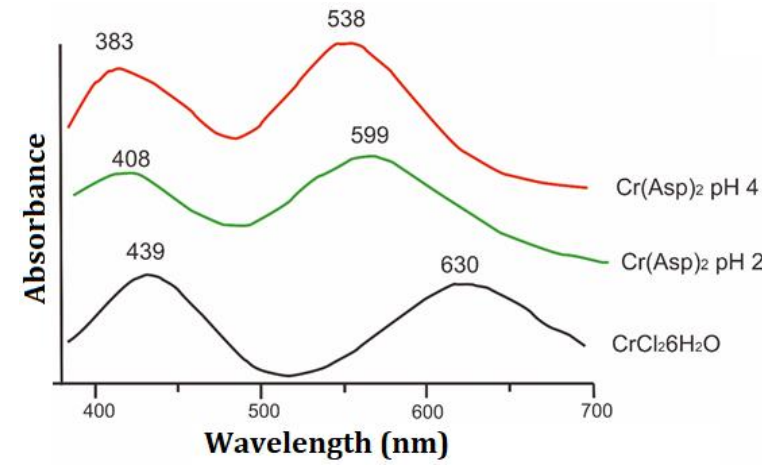

a

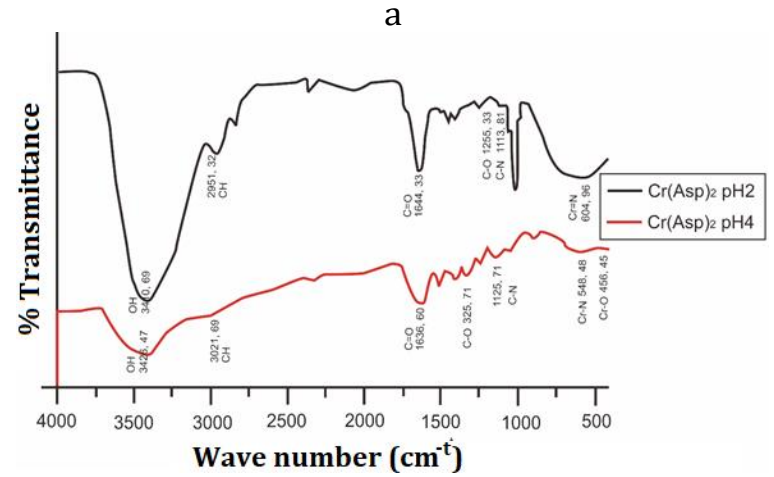

b

Figure 2. The spectra of (a) Uv-Vis; (b) FT-IR of the $\mathrm{Cr}(\mathrm{Asp})_{2} \mathrm{Cl}_{2}$ compound

At $\mathrm{pH} 2$, there is $\mathrm{OH}$ absorption at $3410.69 \mathrm{~cm}^{-1}, \mathrm{CH}$ stretching vibrations at $2951.32 \mathrm{~cm}^{-1}, \mathrm{C}=0$ absorption at $1644.33 \mathrm{~cm}^{-1}$, $\mathrm{C}-\mathrm{O}$ and $\mathrm{C}-\mathrm{N}$ stretch are visible at 1255.33 and $1113.81 \mathrm{~cm}^{-1}$ (Figure 2 (b)). Furthermore, the $\mathrm{Cr}-\mathrm{N}$ absorption is in the area of $604.96 \mathrm{~cm}^{-1}$ indicating that there is a bond between the $\mathrm{Cr}$ and the $\mathrm{N}$ atoms. On the contrary, at $\mathrm{pH} 4$, there is $\mathrm{OH}$ absorption at 3426 and $47 \mathrm{~cm}^{-1}$, the stretching vibration of $\mathrm{CH}$ at $3021.69 \mathrm{~cm}^{-1}, \mathrm{C}=\mathrm{O}$ absorption at $1636.60 \mathrm{~cm}^{-1}, \mathrm{C}-\mathrm{O}$ and $\mathrm{C}-\mathrm{N}$ stretch were seen at 325.71 and $1156.34 \mathrm{~cm}^{-1}$. The $\mathrm{Cr}-\mathrm{N}$ and $\mathrm{Cr}-\mathrm{O}$ absorption was found in 548.48 and $456.45 \mathrm{~cm}^{-1}$, these values are in agreement to the data reported by Mangamma et al. (2007). Meanwhile, the coordinate covalent bond between metal and ligands can be seen at the wavenumber below $625 \mathrm{~cm}^{-1}$. Based on the IR spectra in Figures 2 (a) and (b), the synthesized compound used for the antidiabetic test is $\mathrm{Cr}(\mathrm{Asp})_{2} \mathrm{Cl}_{2}$. It was obtained as the result of synthesis at $\mathrm{pH} 4$, which indicates the formation of $\mathrm{Cr}-\mathrm{N}$ and $\mathrm{Cr}-\mathrm{O}$ bonds from aspartic acid. The SEM/EDX measurement results for the $\mathrm{Cr}(\mathrm{Asp})_{2} \mathrm{Cl}_{2}$ complex show that there are still $\mathrm{Cl}$ ligands. Therefore, the aspartate ligand does not completely replace the water molecule and the $\mathrm{Cl}$ atom (Figure 3 and Table I).

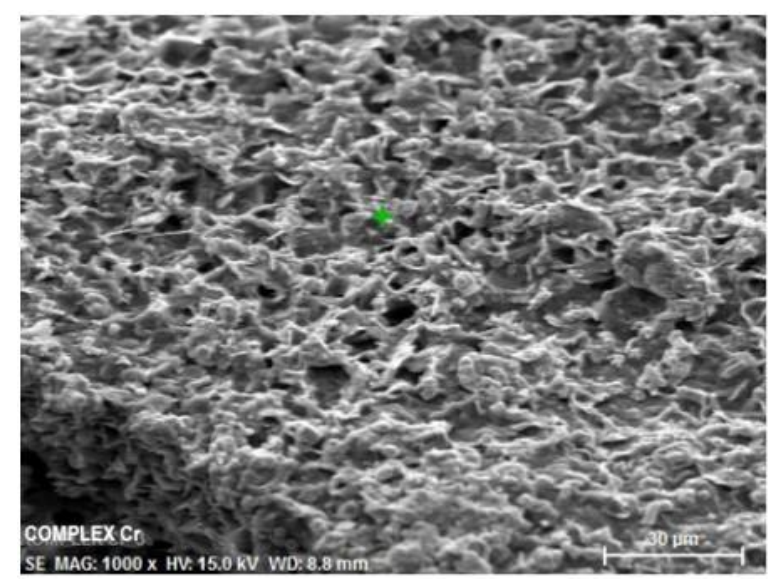

a

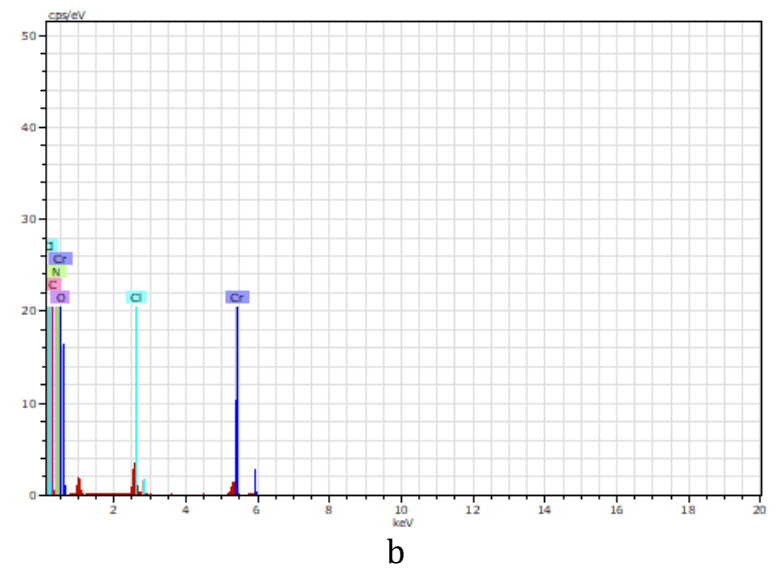

Figure 3. (a) SEM image; (b) EDX spectra of the $\operatorname{Cr}($ Asp $){ }_{2} \mathrm{Cl}_{2}$ compound

\section{The Synthesis of $\mathrm{Cu}(\mathrm{Asp}) \mathrm{Cl}_{2}$}

The synthesis results of $\mathrm{Cu}(\mathrm{Asp}) \mathrm{Cl}_{2}$ at $\mathrm{pH} 7$ in the form of a blue solid at $1 \mathrm{~h}$ are $0.2083 \mathrm{~g} ; 2 \mathrm{~h}$, $0.2258 \mathrm{~g} ; 3 \mathrm{~h}, 0.2967 \mathrm{~g}$; and $4 \mathrm{~h}$, and $0.2110 \mathrm{~g}$; and most solids are found in the time of $3 \mathrm{~h}$. The synthesis at $\mathrm{pH} 2$ obtained a green solid as much as $0.2935 \mathrm{~g}$, pH 4, 5, and 6 having a weight of 0.3095 , 0.2712 , and $0.2876 \mathrm{~g}$, respectively. The molecular structure formed from the reaction between $\mathrm{CuCl}_{2} \cdot 2 \mathrm{H}_{2} \mathrm{O}$ and aspartic acid in distilled water is $\mathrm{Cu}(\mathrm{Asp}) \mathrm{Cl}_{2}$ compound (Figure 4). 
Table I. The composition of metal element in $\mathrm{Cr}(\mathrm{Asp})_{2} \mathrm{Cl}_{2}$ measured with EDX

\begin{tabular}{|c|c|c|c|c|c|c|}
\hline EI & AN & Series & C. Norm [wt. \%] & C. Atom [wt. \%] & C. Error [at. \%] & (1 sigma) [wt. \%] \\
\hline 0 & 8 & K-Series & 35.25 & 39.84 & 37.29 & 5.54 \\
\hline $\mathrm{C}$ & 6 & K-Series & 30.71 & 34.64 & 43.20 & 4.94 \\
\hline $\mathrm{N}$ & 7 & K-Series & 12.88 & 14.52 & 15.53 & 3.05 \\
\hline $\mathrm{Cl}$ & 17 & K-Series & 5.33 & 6.02 & 2.54 & 0.22 \\
\hline \multirow[t]{2}{*}{$\mathrm{Cr}$} & 24 & K-Series & 4.42 & 4.98 & 1.44 & 0.17 \\
\hline & & Total & 88.65 & 100.00 & 100.00 & \\
\hline
\end{tabular}<smiles>CC(C)C1N[Ge](Cl)(Cl)OC1=O</smiles>

Figure 4. The reaction between $\mathrm{Cu}(\mathrm{II})$ and aspartic acid

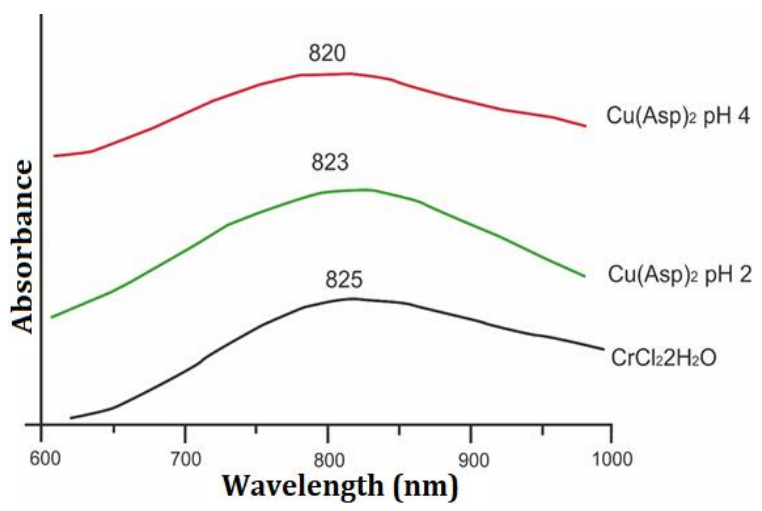

a

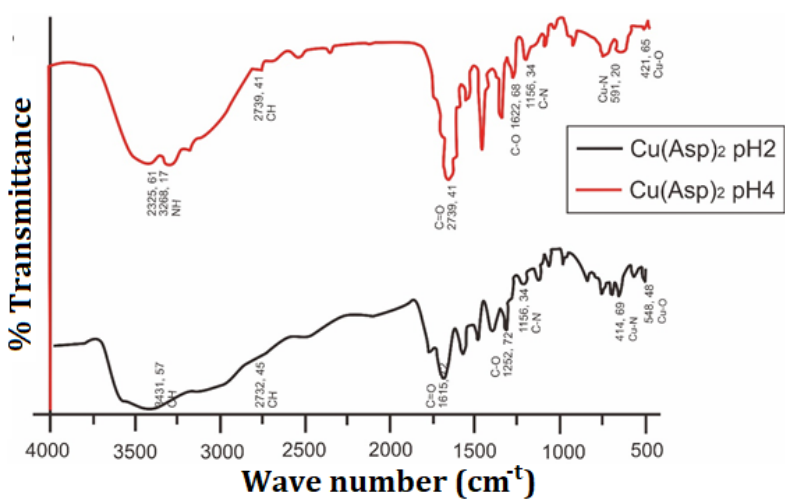

$\mathrm{b}$

Figure 5. The spectra of (a) Uv-Vis; (b) FT-IR of the $\mathrm{Cu}(\mathrm{Asp}) \mathrm{Cl}_{2}$ compound

$\mathrm{CuCl}_{2} \cdot 2 \mathrm{H}_{2} \mathrm{O}$ metal has a maximum wavelength $\left(\lambda_{\max }\right)$ at $825 \mathrm{~nm}$ (Figure 5.a). Meanwhile, in the complex compounds formed, $\mathrm{Cu}(\mathrm{Asp}) \mathrm{Cl}_{2} \mathrm{pH} 2$ is absorbed at a wavelength of $823 \mathrm{~nm}$ and $\mathrm{Cu}(\mathrm{Asp}) \mathrm{Cl}_{2} \mathrm{pH} 4$ is at $820 \mathrm{~nm}$. This causes a shift to a smaller $\lambda_{\max }$ due to the reaction between $\mathrm{CuCl}_{2} \cdot 2 \mathrm{H}_{2} \mathrm{O}$ and aspartate. Therefore, the $\mathrm{CuCl}_{2} \cdot 2 \mathrm{H}_{2} \mathrm{O}$ complex changes into a new $\mathrm{Cu}(\mathrm{II}) ; \mathrm{H}_{2} \mathrm{O}$ and $\mathrm{Cl}$ ligands are replaced by aspartate as a new ligand that binds coordination with $\mathrm{Cu}(\mathrm{II})$ to form the $\mathrm{Cu}(\mathrm{Asp}) \mathrm{Cl}_{2}$ complex.

At $\mathrm{pH} 2$, there is $\mathrm{OH}$ absorption at $3431.57 \mathrm{~cm}^{-1}, \mathrm{CH}$ stretching vibration at $2732.45 \mathrm{~cm}^{-1}, \mathrm{C}=\mathrm{O}$ absorption at $1615.72 \mathrm{~cm}^{-1}$, $\mathrm{CO}$ and $\mathrm{CN}$ stretch at 1252.72 and $1156.34 \mathrm{~cm}^{-1}$, and the $\mathrm{Cr}-\mathrm{N}$ and $\mathrm{Cr}-\mathrm{O}$ absorption were 548.48 and $414.69 \mathrm{~cm}^{-1}$ (Figure 5.b). At pH 4, there is no $\mathrm{OH}$ absorption, and $\mathrm{NH}$ absorption appears at $3325.61-3268.17 \mathrm{~cm}^{-1}, \quad \mathrm{CH}$ stretching vibration is at $2739.41 \mathrm{~cm}^{-1}, \mathrm{C}=\mathrm{O}$ absorption at $1622.68 \mathrm{~cm}^{-1}$, $\mathrm{CO}$ and $\mathrm{CN}$ peaks were observed at 1234.45 and $1156.34 \mathrm{~cm}^{-1}$ (Figure 5.b). Also, $\mathrm{Cu}-\mathrm{N}$ and $\mathrm{Cu}-\mathrm{O}$ absorption was found at 591.20 and $421.65 \mathrm{~cm}^{-1}$, these values are close the reported values reported by Al-Jeboori and Al-Shimiesawi (2013) and the coordinate covalent bond between metal and ligands can be seen at the wavenumber below $625 \mathrm{~cm}^{-1}$. The elements in the $\mathrm{Cu}(\mathrm{Asp}) \mathrm{Cl}_{2}$ complex characterization using SEM/EDX (Figure 6 and Table II). 
Table II. The composition of metal element of $\mathrm{Cu}(\mathrm{Asp}) \mathrm{Cl}_{2}$ using EDX measurement

\begin{tabular}{ccccccc}
\hline EI & AN & Series & C. Norm [wt. \%] & C. Atom [wt. \%] & C. Error [at. \%] & (1 sigma) [wt. \%] \\
\hline $\mathrm{Cu}$ & 29 & K-Series & 24.98 & 51.32 & 19.03 & 1.00 \\
$\mathrm{C}$ & 6 & K-Series & 11.21 & 23.04 & 45.19 & 2.24 \\
$\mathrm{O}$ & 8 & K-Series & 8.29 & 17.04 & 23.09 & 1.54 \\
$\mathrm{~N}$ & 7 & K-Series & 2.38 & 4.88 & 8.22 & 0.83 \\
$\mathrm{Cl}$ & 17 & K-Series & 1.81 & 3.72 & 2.47 & 0.11 \\
& & Total & 48.68 & 100.00 & 100.00 & \\
\hline
\end{tabular}

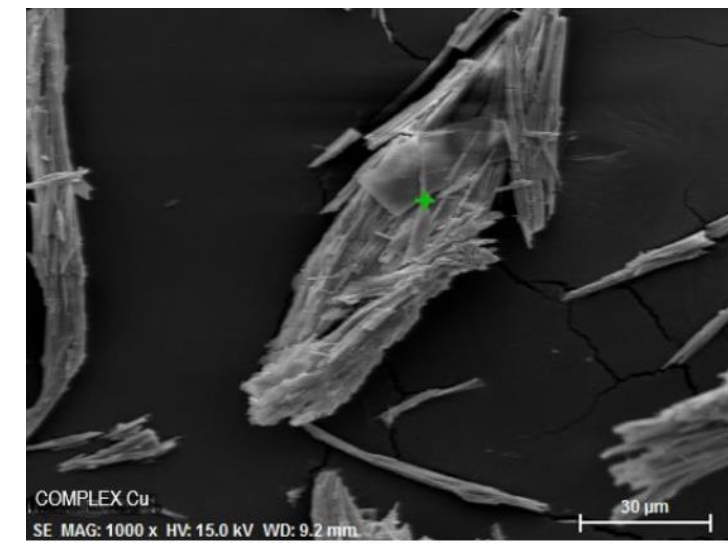

a

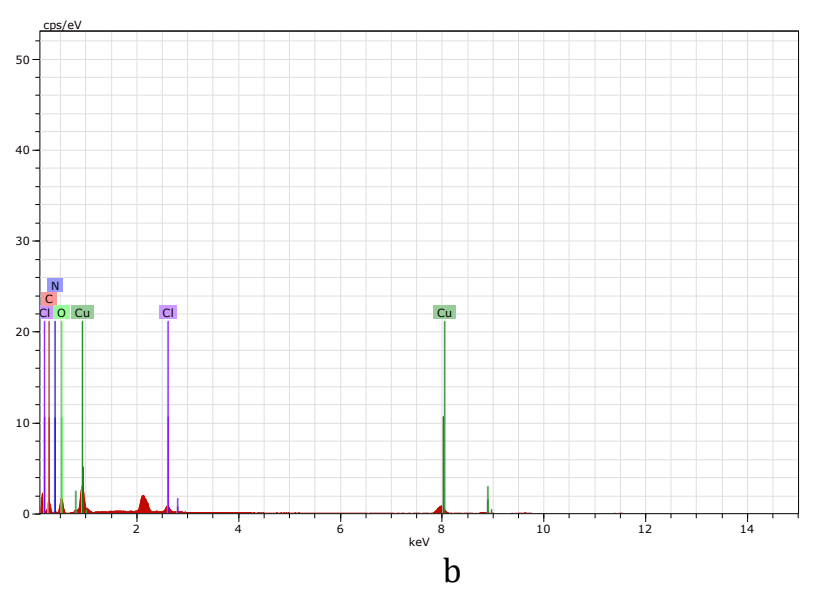

Figure 6. (a) SEM image; (b) EDX spectra of the $\mathrm{Cu}\left(\right.$ Asp) $\mathrm{Cl}_{2}$ compound

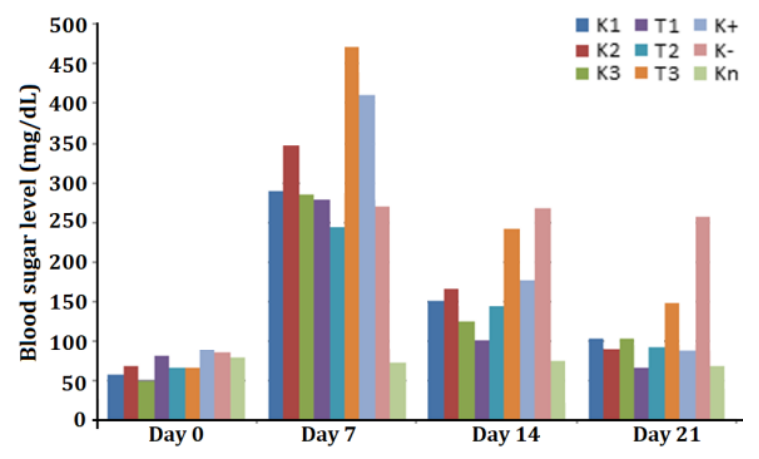

Figure 7. The changes in blood glucose levels in mice

The SEM/EDX measurement results for $\mathrm{Cu}$ (Asp) $\mathrm{Cl}_{2}$, indicating that the complex formed contains a $\mathrm{Cl}$ atom (Figure 6). Therefore, only one molecular aspartate ligand is attached to the $\mathrm{Cu}$ atom since the complex formed is $\mathrm{Cu}\left(\right.$ Asp) $\mathrm{Cl}_{2}$.

\section{Antidiabetic Test}

Results of observations regarding the effect of the complex compounds $\mathrm{Cr}(\mathrm{Asp})_{2} \mathrm{Cl}_{2}$ and $\mathrm{Cu}(\mathrm{Asp}) \mathrm{Cl}_{2}$ on the decrease in total blood glucose levels of alloxan-induced mice (Figure 7).
The blood glucose levels of the mice were measured on day 0 and for each mouse, it ranged from 57.67 to $89.33 \mathrm{mg} / \mathrm{dL}$. Subcutaneous alloxan induction treatment was given at a dose of $150 \mathrm{mg} / \mathrm{kgbw}$ to put them in an antidiabetic condition. Alloxan was chosen as a diabetogenic agent because of its ability to display the antidiabetic effects within 2-3 days of treatment (Lelono and Tachibana, 2013). The induction causes blood glucose levels of mice to fluctuate for 8-48 h, which includes the phases of hyperglycemia and hypoglycemia that occur alternately before the occurrence of permanent 
Table III. Percentage of blood glucose in mice

\begin{tabular}{lccccccccc}
\hline Group & \multicolumn{3}{c}{$\mathbf{C r}\left(\mathbf{A s p} \mathbf{2}_{\mathbf{2}} \mathbf{C l}_{\mathbf{2}}\right.$} & \multicolumn{3}{c}{$\mathbf{C u}(\mathbf{A s p}) \mathbf{C l}_{\mathbf{2}}$} & \multicolumn{3}{c}{ Control } \\
\cline { 2 - 11 } $\begin{array}{l}\text { Treatment } \\
\text { \%GL }\end{array}$ & $\mathrm{K} 1$ & $\mathrm{~K} 2$ & $\mathrm{~K} 3$ & $\mathrm{~T} 1$ & $\mathrm{~T} 2$ & $\mathrm{~T} 3$ & $\mathrm{~K}+$ & $\mathrm{K}-$ & $\mathrm{Kn}$ \\
\cline { 2 - 11 } & 64.4419 & 74.1874 & 63.6257 & 76.1337 & 61.8852 & 68.5734 & 78.3455 & 4.44444 & 4.62963 \\
\hline
\end{tabular}

Table IV. The average of blood glucose levels in mice after given $\operatorname{Cr}(\mathrm{Asp})_{2} \mathrm{Cl}_{2}$ and $\mathrm{Cu}(\mathrm{Asp}) \mathrm{Cl}_{2}$ compounds

\begin{tabular}{|c|c|c|c|}
\hline $\begin{array}{l}\text { Treatment } \\
\mathrm{Cr}_{(\text {Asp })_{2} \mathrm{Cl}_{2}}\end{array}$ & $\begin{array}{l}\text { Mean Blood Glucose Levels of Mice } \\
\text { (Mean } \pm \text { Std. Deviation) }\end{array}$ & $\begin{array}{l}\text { Treatment } \\
\mathrm{Cu}\left(\text { Asp) } \mathrm{Cl}_{2}\right.\end{array}$ & $\begin{array}{l}\text { Mean Blood Glucose Levels of Mice } \\
\text { (Mean } \pm \text { Std. Deviation) }\end{array}$ \\
\hline $\mathrm{K} 1$ & $103.00 \pm 30.61^{\mathrm{a}}$ & $\mathrm{T} 1$ & $66.67 \pm 17.15^{\mathrm{a}}$ \\
\hline $\mathrm{K} 2$ & $90.00 \pm 36.59^{a}$ & $\mathrm{~T} 2$ & $93.00 \pm 61.02^{\mathrm{a}}$ \\
\hline K3 & $103.67 \pm 18.50^{a}$ & T3 & $148.33 \pm 25,54^{b}$ \\
\hline $\mathrm{K}(+)$ & $89.00 \pm 4.00^{\mathrm{a}}$ & $\mathrm{K}(+)$ & $89.00 \pm 4.00^{\mathrm{a}}$ \\
\hline $\mathrm{K}(-)$ & $224.67 \pm 16.50^{\mathrm{b}}$ & $\mathrm{K}(-)$ & $224.67 \pm 16,50^{c}$ \\
\hline $\mathrm{K}(\mathrm{n})$ & $68.67 \pm 9.60^{\mathrm{a}}$ & $\mathrm{K}(\mathrm{n})$ & $68.67 \pm 9.60^{\mathrm{a}}$ \\
\hline
\end{tabular}

Note: Figures followed by a different superscript show a significant difference based on the 5\% LSD test

hyperglycemia (Lenzen, 2008). In addition, the results on the seventh day showed an increase in blood glucose levels in mice. The increase was quite diverse, because the response of the body of each mouse to alloxan was different, resulting in a different increase in blood glucose levels. This is due to the damage in the $\beta$ cells of the pancreas, which is a site for the secretion of the hormone insulin. The mechanism of action of alloxan in damaging pancreatic $\beta$ cells occurs through the formation of reactive oxygen compounds that form superoxide radicals from redox reactions. Through the redox cycle, a highly reactive hydroxyl is formed and it caused rapid damage to pancreatic $\beta$ cells.

Blood glucose levels of mice increased between 244 and $472 \mathrm{mg} / \mathrm{dL}$ and those with diabetes in the $\mathrm{K} 1, \mathrm{~K} 2, \mathrm{~K} 3, \mathrm{~T} 1, \mathrm{~T} 2, \mathrm{~T} 3, \mathrm{~K}(+)$, and $\mathrm{K}(-)$ treatment groups experienced polyuria (increased urine volume), as shown in the damp and smelly cage conditions. For 14 days, $\mathrm{Cr}(\mathrm{Asp}){ }_{2} \mathrm{Cl}_{2}$ and $\mathrm{Cu}(\mathrm{Asp}) \mathrm{Cl}_{2}$ were given to mice in the $\mathrm{K} 1, \mathrm{~K} 2, \mathrm{~K} 3, \mathrm{~T} 1, \mathrm{~T} 2$, and $\mathrm{T} 3$ treatment groups, and glibenclamide compound was orally administered in the $\mathrm{K}(+)$ treatment group. The results of measuring blood glucose levels in the $\mathrm{K} 1, \mathrm{~K} 2, \mathrm{~K} 3, \mathrm{~T} 1, \mathrm{~T} 2, \mathrm{~T} 3$, and $\mathrm{K}(+)$ on the 14th and $21^{\text {st }}$ days showed a gradual decrease in blood glucose levels. Also, the effect of the treatment can be observed from the percent glucose lowering (\%GL), which is the percentage reduction in blood sugar levels
(Sharma et al., 2011; Pelin et al., 2017 ). The $\% \mathrm{GL}$ is the difference between the sugar content (average) of the diabetes mice group before and after treatment.

The percent results of blood glucose in mice, and in the $\mathrm{Cr}(\text { Asp })_{2} \mathrm{Cl}_{2}$ group, K2 treatment had the highest \%GL value, accounting for $74.1874 \%$ (Table III). Meanwhile, in the $\mathrm{Cu}(\mathrm{Asp}) \mathrm{Cl}_{2}$ control group, $\mathrm{T} 1$ treatment had the highest \%GL, that is, $76.1337 \%$. The $\mathrm{K} 2$ and $\mathrm{T} 1$ treatment groups had $\% \mathrm{GL}$ values that were close to the positive control (glibenclamide) of 78.3455\%. Therefore, $\mathrm{Cr}(\mathrm{Asp})_{2} \mathrm{Cl}_{2}$ and $\mathrm{Cu}(\mathrm{Asp}) \mathrm{Cl}_{2}$ groups have almost a similar level of effectiveness as glibenclamide.

The results of one-way analysis of variance test on grade values blood glucose in each treatment group show that $\mathrm{Cr}(\mathrm{Asp})_{2} \mathrm{Cl}_{2}$ has a significant effect $(p<0.05)$. After administering $\mathrm{Cr}(\mathrm{Asp})_{2} \mathrm{Cl}_{2}$ compound, the blood glucose increased. The following table shows the mean blood sugar of mice after giving $\mathrm{Cr}(\mathrm{Asp})_{2} \mathrm{Cl}_{2}$ compound on the $21^{\text {st }}$ day.

The results of the smallest significant difference measurement of the mean blood sugar levels against the $\mathrm{Cr}(\mathrm{Asp})_{2} \mathrm{Cl}_{2}$ compound administered (Table IV). There was a significant difference between $\mathrm{K}(-)$ and $\mathrm{K} 1, \mathrm{~K} 2$, $\mathrm{K} 3, \mathrm{~K}(+)$, and $\mathrm{K}(\mathrm{n})$ treatments. On the contrary, there was no significant difference between $\mathrm{K}(\mathrm{n}), \mathrm{K} 2, \mathrm{~K} 3, \mathrm{~K}(+)$, and $\mathrm{K} 1$ treatments. 
Therefore, K1, K2, K3, and K(+) treatments have a value that is almost similar to $K(n)$ and very different from $\mathrm{K}(-)$ treatment.

As shown by the results of measuring blood glucose levels in mice by giving $\mathrm{Cu}$ (Asp) $\mathrm{Cl} 2$ compounds in Table 2, there was a significant difference between $\mathrm{K}(-)$ and $\mathrm{T} 1, \mathrm{~T} 2$, $\mathrm{K}(+)$, and $\mathrm{K}(\mathrm{n})$ treatments. Furthermore, there was a significant difference between $\mathrm{T} 3$ and $\mathrm{T} 1$, $\mathrm{T} 2, \mathrm{~K}(+)$, and $\mathrm{K}(\mathrm{n})$ treatments. In contrast, there was no significant difference between $\mathrm{K}(\mathrm{n})$ and $\mathrm{T} 1, \mathrm{~T} 2$, and $\mathrm{K}(+)$ treatments. These results are similar to those of previous studies using $\mathrm{Cr}(\mathrm{Ala})_{3}$ and $\mathrm{Cu}(\mathrm{Ala})_{2}$ complexes to reduce glucose levels in mice (Ambarwati et al., 2020).

Based on the study that has been conducted, the compounds synthesized, $\mathrm{Cr}(\mathrm{Asp})_{2} \mathrm{Cl}_{2}$ and $\mathrm{Cu}(\mathrm{Asp}) \mathrm{Cl}_{2}$, can reduce blood glucose levels in mice.

\section{CONCLUSIONS}

The synthesis of $\mathrm{CrCl}_{3} \cdot 6 \mathrm{H}_{2} \mathrm{O}$ compound with aspartic acid obtained maximum results at $\mathrm{pH} 4$ with a synthesis time of $4 \mathrm{~h}$ resulting in a light purple solid with a yield of $95.14 \%$. The synthesis of $\mathrm{CuCl}_{2} \cdot 2 \mathrm{H}_{2} \mathrm{O}$ compounds with aspartic acid obtained a maximum result at $\mathrm{pH} 4$ with a time of $3 \mathrm{~h}$, and resulted in blue solid with a yield of $95.02 \%$. The in vivo antidiabetic test showed that the $\mathrm{Cr}(\mathrm{Asp})_{2} \mathrm{Cl}_{2}$ and $\mathrm{Cu}(\mathrm{Asp}) \mathrm{Cl}_{2}$ complex compounds possessed an effect on reducing blood glucose levels after alloxan induction. This was proven with \%GL value of $74.1874 \%$ for $\mathrm{Cr}(\mathrm{Asp})_{2} \mathrm{Cl}_{2}$ at dose II and $76.1337 \%$ for $\mathrm{Cu}(\mathrm{Asp}) \mathrm{Cl}_{2}$ at dose I.

\section{ACKNOWLEDGMENTS}

The authors are grateful to the University of Lampung, for the assistance of the UNILA $2020 \mathrm{BLU}$ (No. 1508/UN26.21/PN/2020) research funding. Also grateful to thd Integrated Laboratory and Center for Technology Innovation (LTSIT) of the University of Lampung for the assistance of the synthesis compound, and special thanks go to Enago (www.enago.com) for the English language proofread and review.

\section{REFERENCES}

Al-Jeboori FHA and Al-Shimiesawi TAM. 2013. Synthesis and investigation of complex formation between amino acid (glycine) and various metal ion by using spectroscopic methods. Journal of
Chemichal Pharmaceutical Research 5(11):318-21.

Ambarwati Y., Septiani L., Bahri S., Yandri, Hadi S., Kesumaningrum ND., 2020. Antidiabetic Bioactivity Test of Chromium(III) and Copper(II) Complex Compounds On Mice (Mus musculus L.). IOP Conf. Ser.: Earth Environ. Sci., 537: 012045. https://doi.org/10.1088/17551315/537/1/012045

Anderson RA., 2000. Chromium and the Prevention and Control of Diabetes. Diabetes Metab., 26: 22-27. PMID: 10705100

Annissa, Suhartati T., Yandri, Hadi S., 2017. Antibacterial Activity of Diphenyltin(IV) and Triphenyltin(IV) 3-Chlorobenzoate against Pseudomonas aeruginosa and Bacillus subtilis. Oriental Journal of Chemistry., 33(3): 1133-1139. https://doi.org/10.13005/ojc/330310

Ariastuti R., Fitrawan LOM., Nugroho AE., Pramono S., 2020. Antidiabetes of Combination of Fractionated-extracts of Andrographispaniculataand

Centellaasiaticain Neonatal Streptozotocin-induced Diabetic Rats. Indonesian Journal of Pharmacy, 31(4): 312-322.

https://doi.org/10.22146/ijp.1135

Budiasih KS., Anwar C., Santosa SJ., Ismail H., Sari IP., 2013b. Antihyperglicemic Activity of Some Chromium-Amino Acid Complex in Nicotinamide-Streptozotocin Induced Diabetic Wistar Rats. Journal of Chemichal and Pharmaceutical Research, 5(9):34-39

Budiasih KS., Anwar C., Santoso SJ., Ismail H., 2013a. Synthesis and Characterization of Chromium (III) Complexes with LGlutamic Acid, Glycine and L-Cysteine. World Academy of Science, Engineering and Technology, 78: 1095-1909.

Cefalu WT., Hu FB., 2004. Role of Chromium in Human Health and in Diabetes. Diabetes Care, 27(11): 2741-2751. https://doi.org/10.2337/diacare.27.11. 2741

DeFronzo R., Ferrannini E., Groop L., Henry RR., Herman WH., Holst JJ., Hu FB., Kahn CR., Raz I., Shulman GI., Simonson DC., Testa MA., Weiss R., 2015. Type 2 diabetes mellitus. Nature Reviews Disease Primers 
, 1: Article number 15019 https://doi.org/10.1038/nrdp.2015.19

Gielen M., 2003. An Overview of Forty Years Organotin Chemistry Developed at the Free Universities of Brussels ULB and VUB. Journal of the Brazilian Chemical Society, 14(6): 870-877. https://doi.org/10.1590/S010350532003000600003.

Hadi S, Rilyanti M. 2010. Synthesis and in vitro anticancer activity of some organotin(IV) benzoate compounds. Oriental Journal of Chemistry . 26(3), 775-779.

Hadi S., Afriyani H., Anggraini WD., Qudus HI., Suhartati T., 2015. The Synthesis and Potency Study of Some Dibutyltin(IV) Dinitrobenzoate Compounds as Corrosion Inhibitor for Mild Steel HRP in DMSO-HCl Solution. Asian Journal of Chemistry 27(4): 1509-1512. https://doi.org/10.14233/ajchem.2015. 18590

Hadi S., Lestari S., Suhartati S., Qudus HI., Rilyanti M., Herasari D., Yandri Y., 2021. Synthesis and comparative study on the antibacterial activity organotin (IV) 3hydroxybenzoate compounds. Pure and Applied Chemistry, 93: 623-628. https://doi.org/10.1515/pac-20201103

Hadi S., Noviany, Rilyanti M., 2018. In Vitro Antimalarial Activity of Some Organotin(IV) 2-Nitrobenzoate Compounds Against Plasmodium falciparum. Macedonian Journal of Chemistry and Chemical Engineering, 37: 185-191.

https://doi.org/10.5229/JECST.2019.10. 1.29

Hadi S., Rilyanti M., Suharso. 2012. In Vitro Activity and Comparative Studies of Some Organotin (IV) Benzoate Derivatives Against Leukemia Cancer Cell: L-1210. Indonesian Journal of Chemistry, 12(2): 172-177. https://doi.org/10.22146/ijc.21359

Hansch C., Verma RP., 2009. Larvicidal activities of some organotin compounds on mosquito larvae: A QSAR study. European Journal of Medicinal Chemistry, 44(1): 260-273. https://doi.org/ 10.1016/j.ejmech.2008.02.040

Hazani NN., Mohd Y., Ghazali SAISM., Farina Y., Dzulkifli NN., 2019. Electrochemical
Studies on Corrosion Inhibition Behaviour of Synthesised 2acetylpyridine 4-ethyl-3thiosemicarbazone and Its Tin(IV) Complex for Mild Steel in $1 \mathrm{M} \mathrm{HCl}$ Solution. Journal of Electrochemical Science and Technology ., 10(1): 29-36. https://doi.org/10.5229/JECST.2019.10. 1.29

Joshi R., Kumari A., Singh K., Mishra H., Pokharia S., 2020. Triorganotin(IV) complexes of Schiff base derived from 1,2,4-triazole moiety: Synthesis, spectroscopic investigation, DFT studies, antifungal activity and molecular docking studies. Journal of Molecular Structure, 1206: 127639,

Krejpcio Z., 2001. Essentiality of Chromium for Human Nutrition and Health. Polish J. Environ. Stud. 10(6): 399-404.

Kurniasiah H., Nurissalam M., Iswantoro B., Afriyani H., Qudus HI., Hadi S., 2015. The Synthesis, Characterization and Comparative Anticorrosion Study of Some Organotin(IV) 4-Chlorobenzoates. Oriental Journal of Chemistry., 31(4): 2377-2.

383. https://doi.org/10.13005/ojc/310467

Lelono RAA., Tachibana S., 2013. Preliminary Studies of Indonesian Eugenia polyantha Leaf Extracts as Inhibitors of Key Enzymes for Type 2 Diabetes. Journal of the Medical Sciences, 13(2): 103-110. https://doi.org/10.3923/jms.2013.103. 110

Lenzen S., 2008. The mechanism of alloxan and streptozoticin induced diabetes, Diabetologia, 51(2): 216-226. https://doi.org/10.1007/s00125-0070886-7

Lewicki S., Zdanowski R., Krzyżowska M., Lewicka A., Dębski B., Niemcewicz M., Goniewicz M., 2014. The role of Chromium(III) in the organism and its possible use in diabetes and obesity treatment. Annals of Agricultural and Environmental Medicine, 21(2):331-5. https://doi.org 10.5604/12321966.1108599.

Mangamma G., Sairam TN., Dash S., Rajalakshmi M., Kamruddin M., Mittal VK., Narasimhan SV., Arora AK., Sundar CS., Tyagi AK., Raj B., 2007. Spectroscopic Characterization of Nanocrystalline 
Chromium Nitride (CrN). Journal of Nanoscience and Nanotechnology7: 9706. https://doi.org/10.1166/jnn.2007.2004 Olokoba AB., Obateru OA., Olokoba LB., 2012. Type 2 Diabetes Mellitus: A Review of Current Trends. Oman Med. J., 27(4): 269-273. https://doi.org/10.5001/omj.2012.68

Pelin AM., Gavat CC., Balan G., Georgescu CV., 2017. Pharmacological Principles Used in Patient Monitoring with Type 2 Diabetes, Revista de Chimie, 68(2): 378-383. https://doi.org/10.37358/RC.17.2.5457

Rehman W., Badshah A., Khan S., Tuyet LTA., 2009. Synthesis, characterization, antimicrobial and antitumor screening of some diorganotin(IV) complexes of 2[(9H-Purin-6-ylimino)]-phenol.

European Journal of Medicinal Chemistry, 44(10): 3981-3985. https://doi.org/10.1016/j.ejmech.2009. 04.027

Samsuar S., Simanjuntak W., Qudus HI., Yandri Y., Herasari H., Hadi S., 2021. In Vitro Antimicrobial Activity Study of Some Organotin(IV) Chlorobenzoates against Staphylococcus aureus and Escherichia coli. Journal of Advanced Pharmacy Education and Research, 11(2): 17-22. https://doi.org/10.51847/kaijZKAFCO

Sharma M., Siddique MW., Shamim AM., Gyanesh S., Pillai KK., 2011. Evaluation of Antidiabetic and Antioxidant Effects of Seabuckthorn (Hippophaerhamnoides L.) in Streptozotocin-Nicotinamide Induced
Diabetic Rats. The Open Conference Proceedings Journal, 2: 53-58. https://doi.org/10.2174/22102892011 02010053

Sundaramurthy SL., Kannappan G., Gayathri M., Ganesh S., 2016. Synthesis, crystal structures, spectroscopic characterization and in vitro antidiabetic studies of new Schiff base Copper(II) complexes. Journal of Chemical Sciences, 128: 1095-1102. https://doi.org/ 10.1007/s12039-016-1099-8

Thomson KH., Chiles J., Yuen VG., Tse J., Mcneill JH., Orvig C., 2004. Comparison of AntiHyperglycemic Effect among Vanadium, Molybdenum and Other Metal Maltol Complexes. Journal of Inorganic Biochemistry, 98: 683-690. https://doi.org/ 10.1016/j.jinorgbio.2004.01.006.

WHO, The top 10 causes of death. https://www.who.int/news-room/factsheets/detail/the-top-10-causes-ofdeath, 2018. (Accessed on October 20, 2020)

Yang X., Palanichamy K., Ontko AO., Rao MNA., Fang, CX., Ren J., Sreejayan N., 2005. A newly synthetic chromium complexchromium (phenylalanine) improves insulin responsiveness and reduces whole body glucose tolerance. FEBS Lett., 579:

1458-1464. https://doi.org/10.1016/j.febslet.2005. 01.049 